\title{
Identifying antibacterial activity components of cosmos flower extracts
}

\author{
Mijung Kim ${ }^{1}$ Seunghyun Ahn' ${ }^{2}$ Seyeon Park ${ }^{2}$ (D)

\section{코스모스 추출물의 항균활성 성분 탐색}

\author{
김미정 ${ }^{*}$ 안숭현 ${ }^{2} \cdot$ 박세 연 $^{2}$
}

Received: 20 July 2020 / Accepted: 3 September 2020 / Published Online: 30 September 2020

(C) The Korean Society for Applied Biological Chemistry 2020

\begin{abstract}
This study investigated whether the extracts from cosmos flowers exhibit antibacterial activities and identified which components were ascribed to the antibacterial effects. The antibacterial effects of extracts from white, pink, and violet cosmos flowers were observed for $24 \mathrm{~h}$ after inoculation with four kinds of bacteria, including Staphylococcus aureus, Staphylococcus epidermidis, Pseudomonas aeruginosa, and Escherichia coli. Among the three fractions of cosmos flower extracts, the best antibacterial activity against the four bacteria was observed in the extracts isolated from the EtOAc layer. However, the extracts from the $\mathrm{CHCl}_{3}$ layer were also effective against $S$. aureus. Moreover, the first of white, second of pink, and first of violet silica gel fractions (Fr.) isolated from the EtOAc layer exhibited minimal inhibition at a concentration of $0.1 \mathrm{mg} / \mathrm{mL}$. Comparison of NMR and High-Pressure Liquid Chromatography results between silica gel Fr. and apigenin suggested that the effective fractions can contain a component including apigenin moiety.
\end{abstract}

Keywords Apigenin - Cosmos bipinnatus Cav. EtOAc fraction - High-Pressure Liquid Chromatography · Nuclear Magnetic Resonance

Seyeon Park $(\bowtie)$

E-mail: sypark21@dongduk.ac.kr

${ }^{1}$ Department of Health and Cosmetics, Dongduk Women's University, Seoul 02748, Republic of Korea

${ }^{2}$ Department of Applied Chemistry, Dongduk Women's University, Seoul 02748, Republic of Korea

This is an Open Access article distributed under the terms of the Creative Commons Attribution Non-Commercial License (http://creativecommons. org/licenses/by-nc/3.0/) which permits unrestricted non-commercial use, distribution, and reproduction in any medium, provided the original work is properly cited.
서 론

코스모스(Cosmos bipinnatus Cav.)는 1년생의 내한성초본식물로 여러 해를 걸쳐 씨가 떨어진 곳에 스스로 자라난다[1]. 코스모 스는 국화과에 속하며 멕시코와 미국 남서부에서 자생하는데 흰 색, 분홍색, 자주색 또는 라벤다색의 꽃을 피운다(2). 꽃의 직경 은 $5-8 \mathrm{~cm}$ 정도이며 6 월에서 10 월에 걸쳐서 피는데 순우리말로 살사리꽃이라고 부른다. 코스모스는 자라면 줄기가 1 2 m까지 이르는데 뿌리를 제외한 전체 부위를 추영(秋英)이라고 칭하며 한방의 재료로 사용되고 있다. 약재로 사용되는 추영은 눈의 충 혈과 종기의 치료에 사용되고 있고 민간에서는 간헐열, 황달, 비장 비대증 등의 치료에 코스모스를 활용하여 왔다[3,4]. 코스 모스의 효능이 한방과 민간에서 인정받고 있는데 반해 효능과 관련된 성분에 대한 연구는 활발하지 않고 있다. 코스모스의 성 분에 대한 연구들에는 다음과 같은 연구가 있다. Woo 등의 연 구[5]에서는 코스모스꽃 $80 \% \mathrm{EtOH}$ 환류냉각 추출물의 총 폴 리페놀과 플라보노이드 함량을 측정하였는데 각각 $67.96 \pm 0.19$, $65.46 \pm 2.85 \mathrm{mg} / \mathrm{g}$ 이었다고 하였고 국화과 15 종 식물의 꽃들 중 에서 페놀성 물질 함량이 가장 높다고 보고하고 있다. Woo 등 의 다른 연구[6]에서는 코스모스 지상부의 $80 \% \mathrm{EtOH}$ 냉각환 류 추출물과 초음파 추출물 중에서 초음파 추출물에서 총 페놀 함량과 총 플라보노이드 함량이 각각 $80.70,39.33 \mathrm{mg} \cdot \mathrm{g}^{-1}$ 이 측 정되어 냉각환류 추출물보다 높았다고 하였다. Lee 등의 연구 [7]는 국화과 꽃들의 미백화장품 가능성을 타진하기 위해 $\mathrm{MeOH}$ 추출물과 4 가지 분획물들에 대해 총 페놀함량과 총 플라보노이 드 함량을 조사하였다. 이 연구에서 총 페놀 함량은 흰색 코스 모스꽃의 $n$-hexane 분획물에서 $67.07 \mathrm{mg} \mathrm{GAE} / \mathrm{g} \mathrm{DW}$, 분홍색 코스모스꽃의 $n$-hexane분획물과EtOAc 분획물에서 각각 36.58 , $26.40 \mathrm{mg} \mathrm{GAE} / \mathrm{g} \mathrm{DW}$ 로 국화과 식물들 중에서도 상당히 많은 양을 함유하고 있다고 하였다. 총 플라보노이드 함량도 흰색 코 스모스꽃과 빨간색 코스모스꽃 EtOAc 분획물들에서 54.38, $54.28 \mathrm{mg} \mathrm{NAE} / \mathrm{g} \mathrm{DW}$ 가 측정되어 다른 식물의 분획물에 비해 
서 높게 나타났다고 하였다. 그리고 Shin의 연구[8]에서는 코스 모스꽃 열수 추출물과 $80 \% \mathrm{MeOH}$ 추출물 중에 $\mathrm{MeOH}$ 추출물 에서 총 폴리페놀 함량이 $62.21 \pm 1.92 \mathrm{mg} / \mathrm{g}$, 총 플라보노이드 함 량이 $77.98 \pm 1.90 \mathrm{mg} / \mathrm{g}$ 으로 나타나 열수 추출물보다 함량이 높 았다고 보고하였다. 그러나 열수 추출물에서rosmaricinic acid를 포함한 4종의 페놀산 성분과 플라보노이드 성분 중 quercetin을 분리하였다고 하였다. 페놀성 물질은 자연에서 1,000 가지 이상 의 물질 구조로 존재하고 있어 아직 대부분의 물질들에 대한 생물학적 작용이나 역할을 확실히 규명, 설명하지 못하고 있다. 규명된 페놀성 물질의 작용들을 보면, 항암 작용, 혈압강화 작 용, 피임 작용, 간보호 작용, 진경 작용 등이 있다[9]. 뿐만 아 니라 페놀성 물질 중에는 항균 작용이 있는 물질들이 다수 있 어서 병원균의 침입에 대한 방어 작용과 식물체 내에서의 저항 작용도 한다고 보고되고 있다[10,11]. 천연물 중에는 코스모스 가 국화과 중에서 페놀 또는 플라보노이드 함량이 높다는 연구 들이 있고 항염증, 항산화, 항유전성 활성, 티로시나아제 억제 에 효과, 미백 효과에 대한 성과도 보고되고 있다[7,8,12-14]. 그 리고 코스모스를 에센셜 오일로 추출하여 향기 성분을 분석, 피 부 독성 평가를 한 연구와 항균 효과를 살펴본 연구도 있다[1618]. 코스모스 추출물의 연구는 총 페놀 함량과 플라보노이드 함량을 중심으로 한 in vitro 연구가 대부분이며 항산화 중심의 연구가 주류를 이루고 있다[5-8,19]. 이에 본 연구는 코스모스 꽃의 항균 활성 효과에 대해 살펴보고 항균 작용을 발휘하는 물질을 밝혀 보고자 한다.

\section{재료 및 방법}

\section{실험 재료}

본 연구의 재료인 코스모스(Cosmos bipinnatus Cav.)꽃은 9월에 부산시 사상구 낙동강변의 삼락공원에 서식하는 것을 채집하였 다. 코스모스 중에서도 흰색, 분홍색, 자주색의 3 가지 꽃을 채 취하여 깨끗하게 세척한 후 그늘에서 말려서 실험을 진행하였 다. 코스모스꽃의 항균 활성을 알아보기 위해 4가지 박테리아 를 사용하였다. 그람양성균으로는 황색포도상구균(S. aureus, KCTC 1927; Korean Collection for Type Cultures, Korea), 표피포도상구균(S. epidermidis, KCTC 1917; Korean Collection for Type Cultures, Korea)을 그람음성균으로는 녹농균(P. aeruginosa, KCTC 2004; Korean Collection for Type Culture, Korea), 대장균(E. coli, KCTC 2571; Korean Collection for Type Culture, Korea)이 사용되었다. 박테리아들은Luria-Bertai (LB) 액체 배지에 접종된 뒤에 shaking incubator $\left(37^{\circ} \mathrm{C}, 200\right.$ $\mathrm{rpm})$ 안에서 배양되었다. $\mathrm{LB}$ 배지(1 L 기준)는 증류수 $950 \mathrm{~g}$ 에 tryptone (BD Biosciences, Franklin Lakes, NJ, USA) $10 \mathrm{~g}$ 과 sodium chloride ( $\mathrm{NaCl}$; Sigma-Aldrich, St. Louis, MO, USA) $10 \mathrm{~g}$, yeast extract (Duchefa Biochemie, Haarlem, Netherlands) $5 \mathrm{~g}$ 으로 제조하였다.

Silica gel column chromatography는 silica gel 60 (230400 mesh; Merck KGaA, Darmstadt, Hessen, Germany)으로 실험 을 진행하였다. 또한, High-Pressure Liquid Chromatography (HPLC) 분석에는 methanol, water 등의 용매를 사용하였고 이 는 Fisher Scientific (Pittsburgh, Pennsylvania, USA)에서 구입
하였다.

그 외 chloroform, ethanol, ethyl-acetate, dimethyl sulfoxide (DMSO) 등은 대정화금의 1 급 시약을 사용하였다.

\section{기기}

본 연구 가운데 항균 활성에 관한 실험에 사용된 기기에는 auto clave (Dae Han Bio Link Co., Ltd., Eumseong, Korea), rotary evaporator (Rotavapor R-114; Büchi AG, Flawil, Switzerland), shaker (BF-350SK; BioFree, Seoul, Korea), shaking incubator (VS-8480SF; Vision Scientific Co., Ltd., Daejeon, Korea), micro high speed centrifuge (Micro 17TR; Hanil Science Industrial Co., Ltd., Gimpo, Korea), centrifuge (Union 32R; Hanil Science Industrial Co., Ltd.), microplate reader (Synergy HT; BioTek Instruments, Winooski, VT, USA) 등이 있다. 성분 분석과 관련하여 NMR 측정과 $\mathrm{HPLC}$ 측정을 진행하였다. NMR 측정은 Unity Inova 500 (Agilent technologies, Santa Clara, CA, USA)을 이용하였고 HPLC 측 정에는 iLC3300 (LABOGENE, Eresing, Bavaria, Germany)을 사용하여 측정하였다.

\section{시료의 추출}

본 연구에서 사용된 코스모스꽃은 채취 후 그늘에서 말려 세절 해서 사용하였다. 코스모스 $100 \mathrm{~g}$ 에 $85 \%$ 에탄올을 처리한 후 빛을 차단한 채로 $24 \mathrm{~h}$ 동안 보관였다. 이후 감압 여과와 농축 의 과정을 통해서 시료 추출물을 얻었다. 이런 과정을 3 회 반 복하여 모은 1차 추출물에 클로로포름 $\left(\mathrm{CHCl}_{3}\right)$ 과 증류수 $(\mathrm{DW})$ 를 첨가하여 분획하여 $\mathrm{CHCl}_{3}$ 층을 분리하고 $\mathrm{DW}$ 층에 에틸아세테이 트 $(\mathrm{EtOAc})$ 를 더하여 $\mathrm{DW}$ 층과 $\mathrm{EtOAc}$ 층을 얻었다. 이 3 가지 분 획물들을 농축하여 1 차 항균 실험을 진행하였다.

\section{Silica gel column chromatogaphy}

코스모스꽃 분획물들 중에서도 $\mathrm{EtOAc}$ 층 추출물이 우수한 항균 효과가 나타남에 따라 균의 성장을 저지하는 물질에 대해 알아 보기 위해 silica gel column chromatograpy를 실시하였다. Column관에 silica gel 60 을 시료량 대비 100배로 충전한 후 전개용매를 2 3번에 나누어 부어주면서 적셔주었다. 전개용매 는 chloroform : methanol : hexane $=7: 4: 1$ 비율로 제조하였다. 전 개용매로 세척되어진 silica gel 위에 전개용매에 용해된 코스모 스꽃 $\mathrm{EtOAc}$ 층 시료를 loading하였다. 전개용매를 column 관 내 로 나누어 가한 후 $5 \mathrm{~mL}$ 씩 이어 받고 이를 $\mathrm{TLC}$ 를 이용하여 동일한 분획물들끼리 모아 감압 농축하였다.

\section{항균 활성 실험}

박테리아 배양하는 액체 배지(LB 배지)는 시험관에 $5 \mathrm{~mL}$ 씩 담 은 후 auto clave에서 멸균 처리를 하였다. 실험에 처리된 균주 들은 액체 배지에서 배양 후 고체 배지에 처리한 후 얻은 single strain을 $18 \mathrm{~h}$ 동안 액체 배지에서 배양하여 얻었다. 실험 에 사용된 균주들은 멸균 처리가 된 액체 배지에 $5 \mu \mathrm{L}$ 씩 접 종되었고 코스모스꽃 시료들은 $0.1,0.2,0.5 \mathrm{mg} / \mathrm{mL}$ 농도로 처 리되었다. LB 배지가 담긴 시험관 마다 처리된 시료와 균주를 고루 섞은 다음 배지를 $100 \mu \mathrm{L}$ 씩 96 well plate에 담아 microplate reader기의 $600 \mathrm{~nm}$ 에서 흡광도값을 측정하였다. 이를 $0 \mathrm{~h}$ 의 측 
정값으로 하고 $6 \mathrm{~h}$ 이후부터 $3 \mathrm{~h}$ 마다 $24 \mathrm{~h}$ 동안 흡광도값을 측 정하였다. 시험관들을 shaking incubator에 보관하면서 측정시간 마다 $\mathrm{LB}$ 배지를 얻어 흡광도값을 측정하여 시간 흐름에 따라 균 의 성장과 이에 대응하는 시료의 활성을 살펴 보았다. 항균 활 성은 대조군의 접종 초기의 $0 \mathrm{~h}$ 흡광도값에 대한 각 시간대별 시료군들의 흡광도값을 시료의 색채값을 제한 효과값으로 나타 내었다. 또한, 항균 활성을 시간 흐름의 연속적인 형태로 관찰 하고 표현하였다.

Relative activity $(\%)=\left(A_{t}-\left[A_{0}-B_{0}\right] / B_{0}\right) \times 100$

$\mathrm{A}_{\mathrm{t}}$ : 시료 처리군(균 접종 후 시간별 상태)의 흡광도 $\mathrm{B}_{0}$ : 시료 무처리된 DMSO 용매 대조군의 흡광도 $(0 \mathrm{~h})$

$\mathrm{A}_{0}$ : 시료 처리군(균이 없는 상태)만의 흡광도 $(0 \mathrm{~h})$

\section{NMR}

코스모스꽃의 항균 활성 물질을 살펴보기 위해silica gel column chromatography 분획물(silica gel 분획물)에 대해 Nuclear Magnetic Resonance (NMR)을 진행하였다. ${ }^{1} \mathrm{H}$ 의 NMR 분광분석은 한국 기초과학지원연구원에 의뢰하여 Unity Inova 500 (499.5, 125.6 $\mathrm{MHz}$ )을 통해서 분석하였다. NMR스펙트럼은 $298 \mathrm{~K}$ 의 온도에서 진행하여 결과를 얻었다.

\section{HPLC}

코스모스꽃 silica gel 분획물들에 함유된 화합물의 분석을 위해 High-Pressure Liquid Chromatography (HPLC)를 시행하였다. HPLC분석은 iLC3300을 통해 진행되었는데 YMC-Pack Polyamine II $(4.6 * 250 \mathrm{~mm}, \mathrm{~S}-5 \mu \mathrm{m}, 12 \mathrm{~nm})$ 의 column을 사용하였다. 분석 은 Methanol: Distilled water $=3: 1$ 혼합액을 $37^{\circ} \mathrm{C}, 20 \mathrm{~min}$ 동 안 흘러 보내면서 wave length는 $250 \mathrm{~nm}$ 에서 추적하였다.

\section{통계 분석}

본 연구의 실험들은 3 회 이상 반복, 시행하였다. 그래프의 값들 은 각 실험들의 횟수에 따르는 평균(mean)과 표준편차(standard deviation)로 나타내었다.

\section{결과 및 고찰}

\section{항균 활성 효과}

세 가지 다른 색깔의 코스모스꽃 추출물들이 박테리아에 대한 성장 저해 효과를 보이는지 알아보기 위해 그람양성균 2 종 $(S$. aureus, S. epidermidis)과 그람음성균 2종(P. aeruginosa, E. coli)으로 항균 실험을 진행하였다.

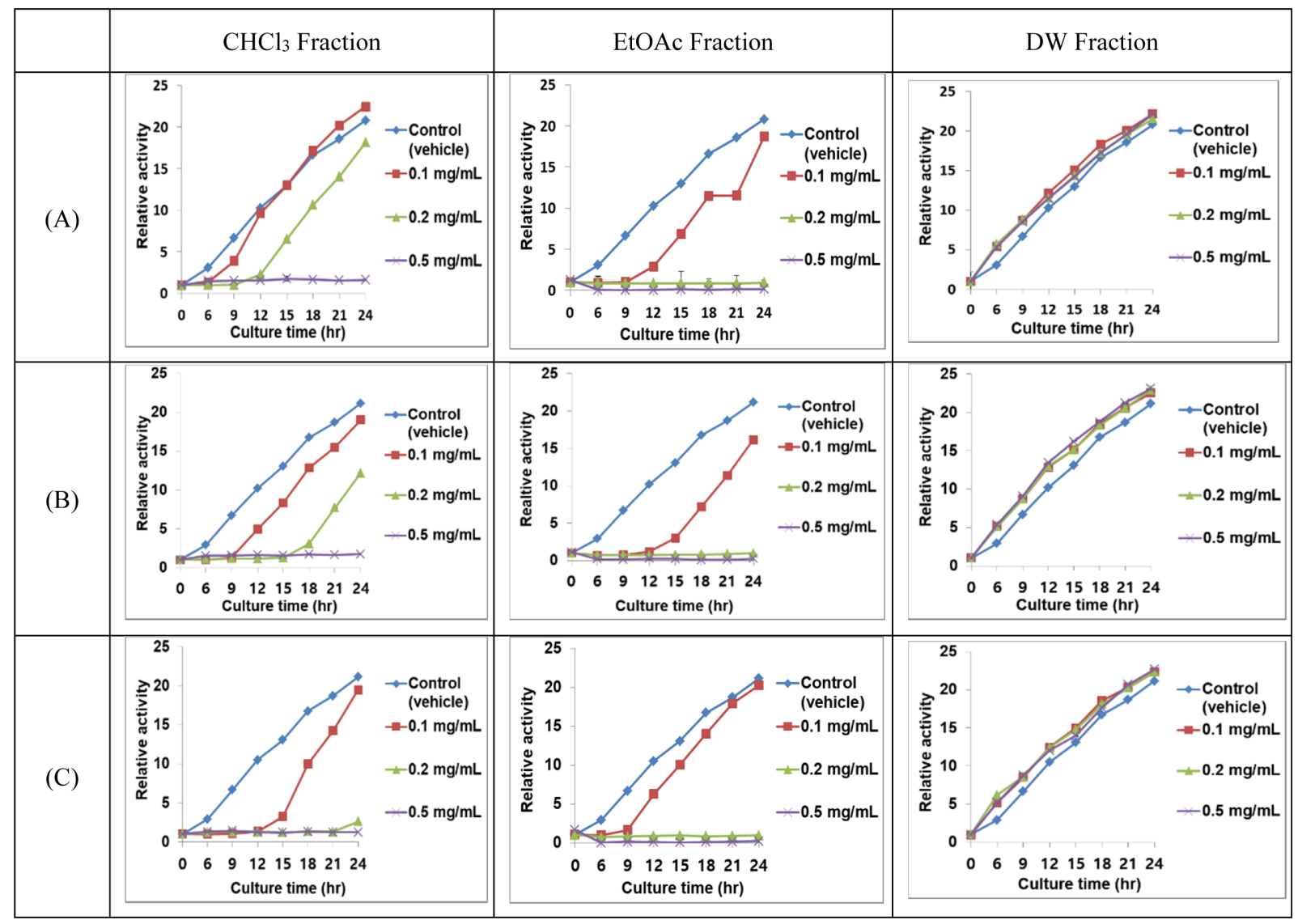

Fig. 1 The extracts from the EtOAc layer inhibited bacterial proliferation activity of $S$. aureus at $0.2 \mathrm{mg} / \mathrm{mL}$ for $24 \mathrm{~h}$, whereas those from the $\mathrm{CHCl}_{3}$ layer showed antibacterial effects at $0.5 \mathrm{mg} / \mathrm{mL}$. The extracts from the DW layer were ineffective 


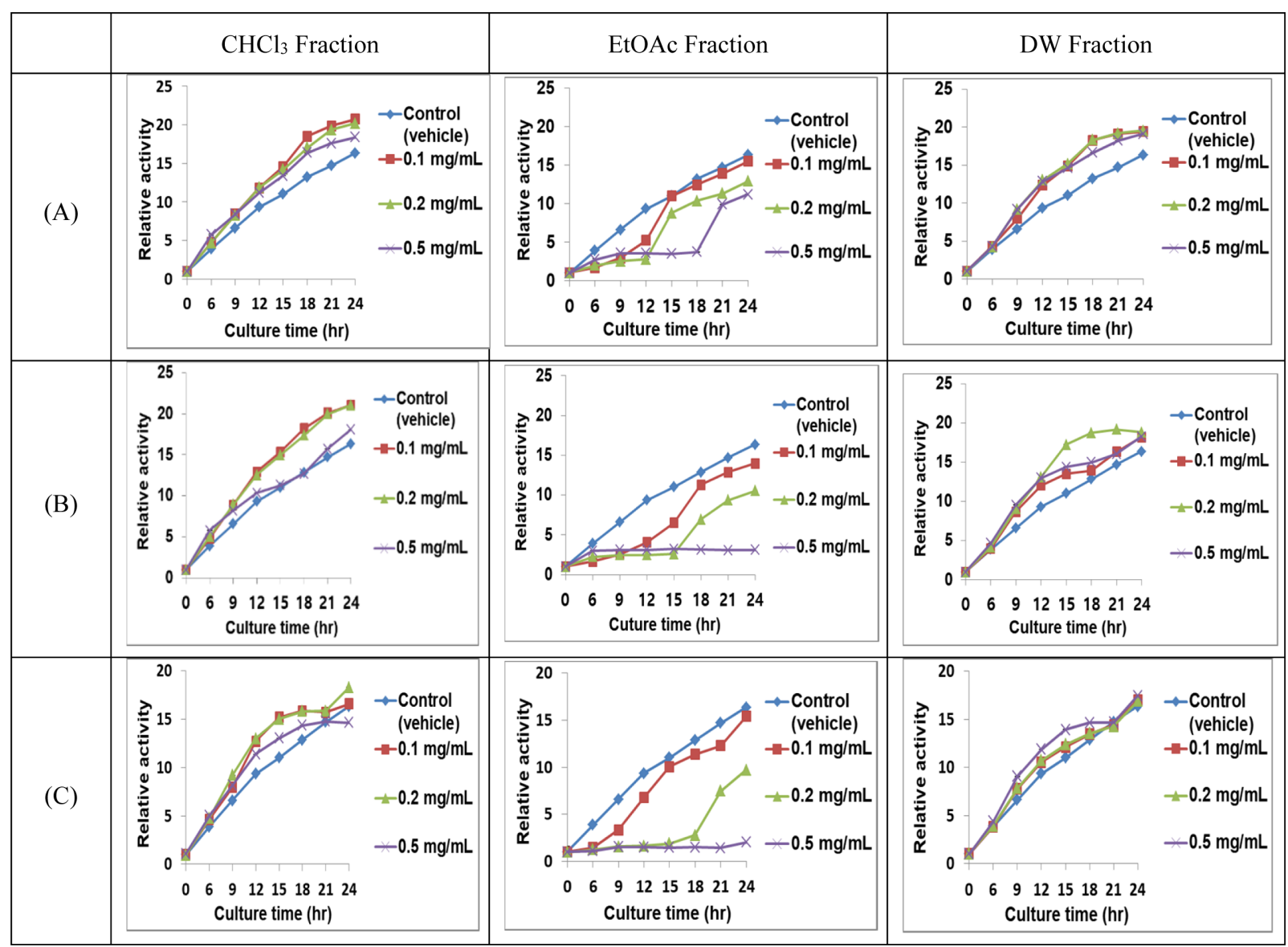

Fig. 2 The pink and violet cosmos flower extracts from the EtOAc layer inhibited the growth of S. epidermidis at $0.5 \mathrm{mg} / \mathrm{mL}$. The effect was also observed in white cosmos flower extracts from the EtOAc layer at a concentration of $0.5 \mathrm{mg} / \mathrm{mL}$. The extracts from the $\mathrm{CHCl}_{3}$ and $\mathrm{DW}$ layers were ineffective

3종의 코스모스꽃 추출물들은 S. aureus에 대해 항균 효과가 있는 것으로 나타났다(Fig. 1). 3종의 코스모스꽃 추출물을 에 틸아세테이트 $(\mathrm{EtOAc})$, 클로로포름 $\left(\mathrm{CHCl}_{3}\right)$, 물 $(\mathrm{DW})$ 의 세가지 용 매로 분획, 분리하여 활성을 추적하였다. 세 가지 분획물 중에 서도 $\mathrm{EtOAc}$ 층 분획물에서 가장 우수한 항균 활성이 관찰되었 고 $\mathrm{CHCl}_{3}$ 층 분획물에서도 균의 성장이 저해되는 양상이 나타 났다. 3종의 코스모스꽃 EtOAc층 분획물들은 모두 S. aureus에 대해 $0.5 \mathrm{mg} / \mathrm{mL}$ 에서 $24 \mathrm{~h}$ 키우는 동안 균의 성장을 억제하였으 며 그 중 분홍색 코스모스꽃 EtOAc 분획물은 $0.2 \mathrm{mg} / \mathrm{mL}$ 에서 도 균의 활성을 저지하였다. 3 종의 코스모스꽃 $\mathrm{CHCl}_{3}$ 층 분획물 들도 $S$. aureus에 대해 $0.5 \mathrm{mg} / \mathrm{mL}$ 에서 모두 항균 효과를 보였 는데 자주색 코스모스꽃 $\mathrm{CHCl}_{3}$ 층 분획물은 $0.2 \mathrm{mg} / \mathrm{mL}$ 에서도 $21 \mathrm{~h}$ 까지 균의 성장을 억제하였다. 분획물 중에 $\mathrm{DW}$ 층은 항균 효과가 없는 것으로 나타났다. Olufunmiso와 Ashafa의 연구(16) 를 보면, 남아프리카에서 자생하는 코스모스의 잎에서 추출한 정유 추출물이 S. aureus에 대해 항균 효과가 있다고 하였는데 $\mathrm{MIC}$ 가 $0.16 \sim 0.31 \mathrm{mg} / \mathrm{mL}$ 라고 하였다. 본 연구에서는 잎이 아닌 꽃의 추출물인 차이가 있으나 코스모스꽃 $85 \%$ 에탄올 추출물 을 분획한 $\mathrm{CHCl}_{3}$ 층 분획물과 $\mathrm{EtOAc}$ 층 분획물에서 각각 0.5 $\mathrm{mg} / \mathrm{mL}$ 와 $0.2 \mathrm{~g} / \mathrm{mL}$ 에서 $\mathrm{MIC}$ 가 측정되어 $S$. aureus에 대해서 유사한 결과가 나타났다. 그러나 Shin의 연구[8]를 보면, 코스
모스꽃 열수추출물과 $80 \%$ 메탄올 추출물이 S.aureus에 대해 $1000 \mathrm{ppm}$ 에서 무처리구에 비해 $17,10.5 \%$ 의 항균 효과가 나타 났다고 하였는데 본 연구에서는 $\mathrm{EtOAc}$ 층 분획물 $0.2 \mathrm{mg} / \mathrm{mL}$ 에 서 균의 성장이 보이지 않아 추출물의 용매와 분획에 따라 항 균 효과에서 차이가 있음을 알 수 있었다.

3종의 코스모스꽃 추출물들은 S. epidermidis에 대해서도 항 균 효과가 있는 것으로 나타났다(Fig. 2). 3종의 코스모스꽃 추 출물 중에서 $\mathrm{EtOAc}$ 층 분획물들은 모두 관찰시간 $24 \mathrm{~h}$ 동안 적 용한 농도에서 모두 항균 활성을 보였다. 분획물 중에서 자주 색 코스모스꽃 분획물 $0.5 \mathrm{mg} / \mathrm{mL}$ 는 균의 성장이 관찰되지 않 았고 분홍색 분획물 $0.5 \mathrm{mg} / \mathrm{mL}$ 는 관찰 $6 \mathrm{~h}$ 이후로는 균의 활 성이 보이지 않았다. 흰색 코스모스꽃 분획물들도 S. epidermidis 에 대해 $24 \mathrm{~h}$ 동안 균의 성장을 억제하였다. 그러나 $\mathrm{CHCl}_{3}$ 층과 $\mathrm{DW}$ 층의 분획물들에서는 S. epidermidis에 대한 항균 효과가 관 찰되지 않았다.

3종의 코스모스꽃 추출물들은 P. aeruginosa에 대해 대해서도 항균 효과가 있는 것으로 나타났다(Fig. 3). 3종의 코스모스꽃 분획물들 중에서도 $\mathrm{EtOAc}$ 층이 가장 우수한 분획물이었고 자주 색 코스모스꽃 $\mathrm{EtOAc}$ 층이 그 중에서도 균의 성장을 효과적으 로 저지하는 것으로 관찰되었다. $\mathrm{CHCl}_{3}$ 층도 관찰시간 동안 미 약하지만 균의 성장을 억제하는 것으로 나타났다. $\mathrm{DW}$ 층은 항 


\begin{tabular}{|c|c|c|c|c|c|c|}
\hline & \multicolumn{2}{|l|}{$\mathrm{CHCl}_{3}$ Fraction } & \multicolumn{2}{|l|}{ EtOAc Fraction } & \multicolumn{2}{|l|}{ DW Fraction } \\
\hline (A) & $\begin{array}{cccccc} & 90 & 12 & 15 & 18 & 21 \\
\text { Culture time (hr) }\end{array}$ & $\begin{array}{c}+ \text { Control } \\
\text { (vehicle) } \\
+-0.1 \mathrm{mg} / \mathrm{mL} \\
+0.2 \mathrm{mg} / \mathrm{mL} \\
-0.5 \mathrm{mg} / \mathrm{mL}\end{array}$ & 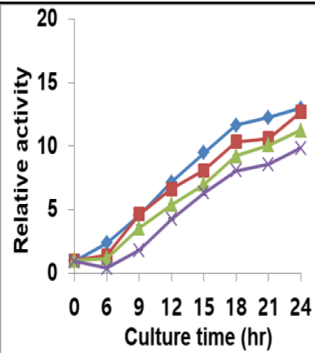 & $\begin{aligned} & \rightarrow-\text { Control } \\
& \text { (vehicle) } \\
- & -0.1 \mathrm{mg} / \mathrm{mL} \\
+ & 0.2 \mathrm{mg} / \mathrm{mL} \\
+ & 0.5 \mathrm{mg} / \mathrm{mL}\end{aligned}$ & $\begin{array}{lllllll} & 20 \\
0 & 6 & 9 & 12 & 15 & 18 & 21 \\
& & 24\end{array}$ & $\begin{aligned} \rightarrow & - \text { Control } \\
& \text { (vehicle) } \\
- & 0.1 \mathrm{mg} / \mathrm{mL} \\
- & 0.2 \mathrm{mg} / \mathrm{mL} \\
- & 0.5 \mathrm{mg} / \mathrm{mL}\end{aligned}$ \\
\hline (B) & 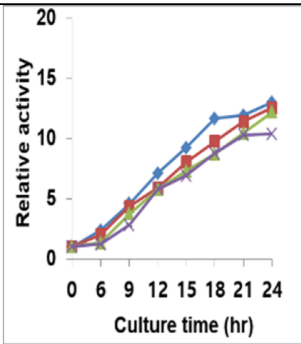 & $\begin{array}{c}\rightarrow \text { Control } \\
\quad \text { (vehicle) } \\
-0.1 \mathrm{mg} / \mathrm{mL} \\
-0.2 \mathrm{mg} / \mathrm{mL} \\
-0.5 \mathrm{mg} / \mathrm{mL}\end{array}$ & 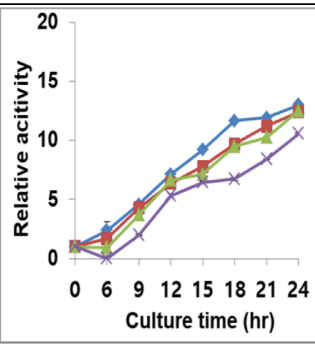 & $\begin{array}{l}\rightarrow-\text { Control } \\
\text { (vehicle) } \\
-0.1 \mathrm{mg} / \mathrm{mL} \\
-0.2 \mathrm{mg} / \mathrm{mL} \\
-0.5 \mathrm{mg} / \mathrm{mL}\end{array}$ & 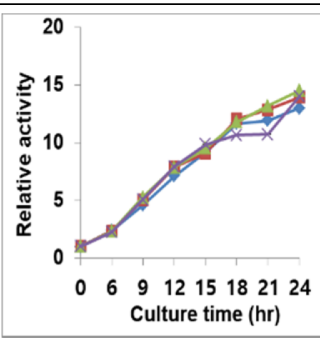 & $\begin{aligned} \rightarrow & - \text { Control } \\
& \text { (vehicle) } \\
- & -0.1 \mathrm{mg} / \mathrm{mL} \\
- & 0.2 \mathrm{mg} / \mathrm{mL} \\
- & 0.5 \mathrm{mg} / \mathrm{mL}\end{aligned}$ \\
\hline (C) & $\begin{array}{lllllll}20 \\
0 & 6 & 9 & 12 & 15 & 18 & 21 \\
\text { Culture time (hr) }\end{array}$ & $\begin{array}{c}\rightarrow-\text { Control } \\
\text { (vehicle) } \\
--0.1 \mathrm{mg} / \mathrm{mL} \\
-0.2 \mathrm{mg} / \mathrm{mL} \\
-0.5 \mathrm{mg} / \mathrm{mL}\end{array}$ & $\begin{array}{lllllll} & 20 \\
0 & 6 & 9 & 12 & 15 & 18 & 21 \\
\text { Culture time (hr) }\end{array}$ & 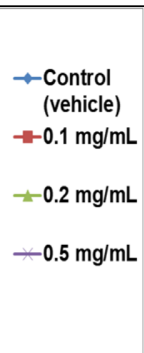 & 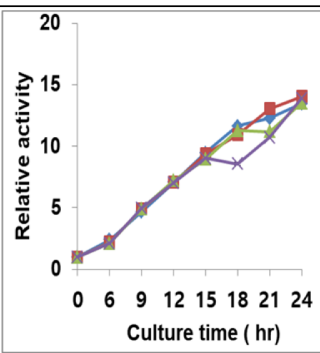 & $\begin{array}{c}\rightarrow-\begin{array}{c}\text { Control } \\
\text { (vehicle) }\end{array} \\
-0.1 \mathrm{mg} / \mathrm{mL} \\
-0.2 \mathrm{mg} / \mathrm{mL} \\
-0.5 \mathrm{mg} / \mathrm{mL}\end{array}$ \\
\hline
\end{tabular}

Fig. 3 The extracts from the EtOAc layer showed antibacterial effects against $P$. aeruginosa. The extracts from the $\mathrm{CHCl}_{3}$ and $\mathrm{DW}$ layers exhibited ineffective to very weak effects

균 효과가 아주 미약하거나 일시적으로 나타났다. Shin의 연구 [8] 결과에서는 코스모스꽃 열수 추출물과 $80 \%$ 메탄올 추출물 이 P. aeruginosa에 대해 처리 농도에 따라 균이 성장하였다고 보고하였다. 본 연구에서는 그람양성균인 S. aureus와 S. epidermids 에 대한 효과만큼은 아니지만 EtOAc층 분획물은 효과가 있었 고 $\mathrm{CHCl}_{3}$ 층 분획물과 $\mathrm{DW}$ 층 분획물에서도 미약하지만 효과가 있어서 상이하였다.

3종의 코스모스꽃 추출물들은 E. Coli에 대해 대해서도 항균 효과가 있는 것으로 나타났다(Fig. 4). 3종의 코스모스꽃 분획 물들 중에서 $\mathrm{EtOAc}$ 층 분획물이 모두 농도의존적으로 균의 성 장을 저지하는 것으로 나타났다. 자주색 코스모스꽃과 분홍색 코스모스꽃이 유사하게 항균 활성을 보였고 흰색 코스모스꽃도 $0.5 \mathrm{mg} / \mathrm{mL}$ 에서는 동일한 농도의 다른 분획물들과 유사한 효과 가 관찰되었다. $\mathrm{CHCl}_{3}$ 층과 $\mathrm{DW}$ 층에서는 항균 효과가 나타나지 않았다. Olufunmiso와 Ashafa의 연구[16]에서는 코스모스잎의 정유 추출물이 $E$. coli에 대해 $0.63 \mathrm{mg} / \mathrm{mL}$ 에서 $\mathrm{MIC}$ 가 관찰되 었다. 그러나 Shin의 연구[8]를 보면, 코스모스꽃 열수 추출물 이 농도에 따라서 균이 성장하였고 코스모스꽃 $80 \%$ 메탄올 추 출물에서는 미약한 항균 효과가 나타났다. 본 연구에서는 EtOAc 층 분획물에서 항균 효과가 관찰되어 Olufunmiso와 Ashafa의 연구(16)와 유사하였고 $\mathrm{CHCl}_{3}$ 층 분획물과 $\mathrm{DW}$ 층 분획물에서 항
균 효과가 없어서 Shin의 연구[8]와 유사하였다. 이를 통해 $E$. coli에 대한 항균 성분이 EtOAc층에 있을 것으로 생각되었다.

3 종의 코스모스꽃 분획물들은 4종의 박테리아 모두에 대해 저지하는 능력에서 차이가 있기는 하였지만 항균 효과를 나타 내었다. 코스모스꽃은 박테리아 중에서도 S. aureus에 대해 낮 은 농도에서도 최소저해농도가 나타났고 분획물 중에서는EtOAc 층과 $\mathrm{CHCl}_{3}$ 층 분획물에서 최소저해농도가 관찰되었다. 그리고 자주색 코스모스꽃 $\mathrm{EtOAc}$ 층 분획물은 S. epidermidis에 대해서 도 $0.5 \mathrm{mg} / \mathrm{mL}$ 에서 최소저해농도가 나타남을 확인할 수 있었 다(Table 1). 종합해 보면, 분획물 중에서는 $\mathrm{EtOAc}$ 층 분획물이 전반적으로 효과가 있는 것으로 나타났고 코스모스꽃 종류 중 에서는 자주색과 분홍색이 흰색 코스모스보다 항균 효과가 있 는 것으로 관찰되었다.

\section{코스모스꽃 Silica gel column chromatography 분흭물의 항균 활성 효과}

3종의 코스모스꽃 추출물들이 보여준 항균 활성 중에서도 EtOAc 층 분획물이 S. aureus에 대해 나타낸 우수한 항균 효과를 좀 더 살펴 보기 위해 Silica gel column chromatography를 실시 하였다. 이를 통해 흰색 코스모스꽃과 분홍색 코스모스꽃 $\mathrm{EtOAc}$ 층 분획물은 5 개로 분획하여 물질을 얻었고 자주색 코스모스꽃 


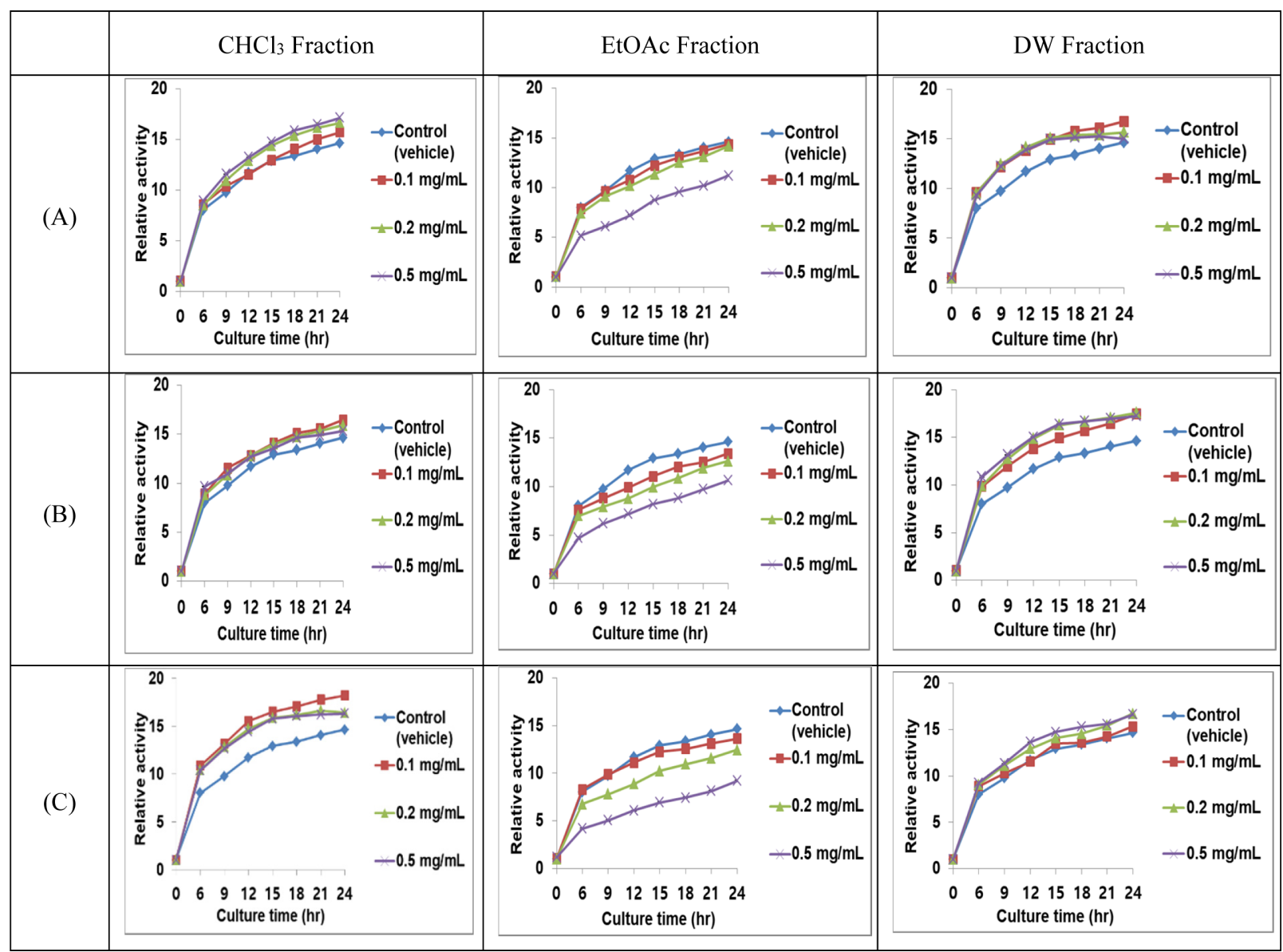

Fig. 4 The extracts from the EtOAc layer showed antibacterial effects against $E$. coli. The $\mathrm{CHCl}_{3}$ layer and extracts from the DW layer exhibited no antibacterial effects. (A) White Cosmos bipinnatus Cav. flowers (B) Pink Cosmos bipinnatus Cav. flowers (C)Violet Cosmos bipinnatus Cav. flowers

$\mathrm{EtOAc}$ 층 분획물은 3 개의 분획물을 얻었다. 물질의 분리는 TLC 를 통해 확인하였다.

코스모스꽃 silica gel column chromatography 분획물(이하, silica gel 분획물)들에 대해 $24 \mathrm{~h}$ 동안 항균 활성 실험을 진행 한 결과 균의 성장이 나타나지 않는 최소저해농도에 대한 결과 가 다음과 같이 나타났다(Table 2).

3종의 코스모스꽃 EtOAc층 silica gel 분획물에서 흰색 코스 모스꽃과 자주색 코스모스꽃은 Fr. 1 의 경우에 관찰 농도 모두 에서 균의 성장이 억제되었으며 최소저해농도가 $0.1 \mathrm{mg} / \mathrm{mL}$ 인 것으로 확인되었다. 분홍색 코스모스꽃은 Fr. 2의 경우에 모든 관찰 농도에서 균의 증식이 나타나지 않았으며 최소저해농도는 $0.1 \mathrm{mg} / \mathrm{mL}$ 로 관찰되었다. 코스모스꽃 EtOAc층 silica gel분획물 중에서도 위의 최소저해농도가 $0.1 \mathrm{mg} / \mathrm{mL}$ 인 분획물뿐만 아니라 $0.2,0.5 \mathrm{mg} / \mathrm{mL}$ 의 관찰 농도에서도 균이 성장하지 않은 분획물 에는 균의 증식을 억제하는데 관여하는 물질이 있을 것으로 생 각된다. Olufunmiso와 Ashafa의 연구(16)를 보면, 코스모스잎 정유 추출물의 성분을 분석하였는데 34 가지의 알려진 성분이 $97.89 \%$ 이고 알려지지 않은 성분이 $1.94 \%$ 이라고 보고하였다. 그 리고 이 성분들 간의 연합이 항균 효과를 나타내는 것으로 판 단하였는데 본 연구에서 항균 물질로 파악한 apigenin은 정유 성분 내에는 분석되지 않았다. 이는 추출 방법에 따른 추출 성
분의 차이에서 비롯된 것으로 생각되었다.

\section{코스모스꽃에 함유된 천연단일 물질의 항균 활성 비교}

3 종의 코스모스꽃 EtOAc층 silica gel 분획물의 관찰 농도 중에 서 최소저해농도가 나타난 흰색 코스모스꽃 $\mathrm{Fr} .1,2$ 와 분홍색 코스모스꽃 Fr. 1, 2, 3 그리고 자주색 코스모스꽃 Fr. 1에 함유 되었을 것으로 유추되는 물질에 대해 항균 효과를 살펴보았다. 우선, 코스모스꽃에 대한 효과 실험에서 표준물질로 사용되는 cosmosiin과 cosmosiin의 구조에서 당이 제거된 형태인 apigenin 을 항균 활성과 관련된 유추물질로 선정하였다. Apigenin의 선 정은 cosmosiin이 코스모스꽃에 함유된 물질 중에 높은 비율을 차지하고 있다는 Saito의 연구(19)와 apigenin이 추출과 분획 과 정에서 cosmosiin에서 당이 제거될 때 나타나는 구조라는 점에 서 근거하였다. 또한, Silica gel 분획물 중에 $0.1 \mathrm{mg} / \mathrm{mL}$ 를 최소 저해농도로 가지는 분획물들에서 apigenin과 유사한 밝은 황색 의 형광빛이 관찰된 점, $\mathrm{Rf}$ 값이 0.88 로 동일한 점을 통해서 선 정하였다.

선정된 $\operatorname{cosmosiin}$ 과 apigenin이 S. aureus에 대해서 항균 활성 을 보이는지 실험을 진행하였다.

실험 결과를 통해 cosmosiin 보다 apigenin이 좀더 항균 효 과가 있는 것으로 관찰되었다(Fig. 5). 관찰 농도 중에서도 100 
Table 1 Comparison of antibacterial activity of Cosmos bipinnatus Cav. flowers fraction against bacteria strains and MIC

\begin{tabular}{|c|c|c|c|c|c|}
\hline \multirow{2}{*}{ Color } & \multirow{2}{*}{ fraction } & \multicolumn{4}{|c|}{ Bateria stains } \\
\hline & & S. aureus & S. epidermidis & P. aeruginosa & E. coli \\
\hline \multirow{3}{*}{ White } & $\mathrm{CHCl}_{3}$ & $\geq 0.5 \mathrm{mg} / \mathrm{mL}$ & - & - & - \\
\hline & EtOAc & $\geq 0.2 \mathrm{mg} / \mathrm{mL}$ & - & - & - \\
\hline & DW & - & - & - & - \\
\hline \multirow{3}{*}{ Pink } & $\mathrm{CHCl}_{3}$ & $\geq 0.5 \mathrm{mg} / \mathrm{mL}$ & - & - & - \\
\hline & EtOAc & $\geq 0.2 \mathrm{mg} / \mathrm{mL}$ & - & - & - \\
\hline & DW & - & - & - & - \\
\hline \multirow{3}{*}{ Violet } & $\mathrm{CHCl}_{3}$ & $\geq 0.2 \mathrm{mg} / \mathrm{mL}$ & - & - & - \\
\hline & EtOAc & $\geq 0.5 \mathrm{mg} / \mathrm{mL}$ & $\geq 0.5 \mathrm{mg} / \mathrm{mL}$ & - & - \\
\hline & DW & - & - & - & - \\
\hline
\end{tabular}

Table 2 Comparison of antibacterial activity of Cosmos bipinnatus Cav. flowers EtOAc silica gel fraction against $S$. aureus and MIC

\begin{tabular}{cccc}
\hline $\begin{array}{c}\text { Color } \\
\text { Fraction }\end{array}$ & $\begin{array}{c}\text { White cosmos } \\
\text { flowers }\end{array}$ & $\begin{array}{c}\text { Pink cosmos } \\
\text { flowers }\end{array}$ & $\begin{array}{c}\text { Violet cosmos } \\
\text { flowers }\end{array}$ \\
\hline Fr. 1 & $0.1 \mathrm{mg} / \mathrm{mL}$ & $0.2 \mathrm{mg} / \mathrm{mL}$ & $0.1 \mathrm{mg} / \mathrm{mL}$ \\
Fr. 2 & $0.2 \mathrm{mg} / \mathrm{mL}$ & $0.1 \mathrm{mg} / \mathrm{mL}$ & - \\
Fr. 3 & - & $0.2 \mathrm{mg} / \mathrm{mL}$ & - \\
Fr. 4 & - & - & \\
Fr. 5 & - & - & \\
\hline
\end{tabular}

$\mu \mathrm{M}$ 가 $50 \mu \mathrm{M}$ 에 비해 $24 \mathrm{~h}$ 동안 균의 증식을 좀더 효과적으로 저지하였다. cosmosiin은 관찰 9 15 h에서 일시적으로 항균 효 과가 나타났다.

이것으로 분획물들 속에 cosmosiin과 apigenin의 형태가 존재 할 가능성이 있을 뿐 아니라 이 중에 apigenin이 우수하지는 않 지만 항균 효과와 관련된 물질 중의 하나일 것으로 확인되었다.

\section{3종 코스모스꽃 Silica gel 분흭물과 apigenin의 NMR과 HPLC 분석}

코스모스꽃 $\mathrm{EtOAc}$ 층 silica gel 분획물들에서 항균 효과에 영향 을 주는 물질에 대해 알아보기 위해 NMR과 HPLC를 진행하 였다.

\section{NMR 분석}

$\mathrm{NMR}$ 분석은 박테리아에 대해 우수한 항균 효과가 나타난 자 주색 코스모스꽃 $\mathrm{Fr}$. 1과 함께 분홍색 코스모스꽃 Fr. 3, 흰색 코스모스꽃 Fr. 3에 대해서 시행하였다.

분획물들에 대한 NMR 분석 결과는 다음과 같다(Fig. 6). 자 주색 코스모스꽃 Fr. 1의 NMR에서 ${ }^{1} \mathrm{H}$ 의 chemical shift는 8.13(d, $J=8.9 \mathrm{~Hz}), 7.65(\mathrm{~s}), 7.27$ (d, $J=2.0 \mathrm{~Hz}), 7.20$ (dd, $J=8.2,2.1 \mathrm{~Hz}), 6.81 \quad(\mathrm{~d}, J=8.2 \mathrm{~Hz}), 6.40 \quad(\mathrm{dd}, J=8.8,2.4$ $\mathrm{Hz}), 6.27(\mathrm{~d}, J=2.3 \mathrm{~Hz}$ )에서 major peak이 나타났으며 이는 분홍색 코스모스꽃 Fr. 3의 $\mathrm{NMR}$ 의 결과와 유사하였다. 이 두 분획물들은 항균 활성 실험에서도 유사한 경향으로 효과를 보 였다. 그러나 흰색 코스모스꽃 Fr. 3의 $\mathrm{NMR}$ 에서 ${ }^{1} \mathrm{H}$ 의 chemical shift는 8.25 (d, $J=9.1 \mathrm{~Hz}), 7.96(\mathrm{~d}, J=8.9 \mathrm{~Hz}), 7.66$ (dd, $J=8.8, \quad 2.5 \mathrm{~Hz}), 7.53$ (d, $J=2.2 \mathrm{~Hz}), 7.31 \quad(\mathrm{~d}, \quad J=2.0 \mathrm{~Hz})$, $7.22(\mathrm{dd}, J=8.3,2.1 \mathrm{~Hz}), 6.81(\mathrm{~d}, J=8.3 \mathrm{~Hz}) / 6.81$ (s) and 6.82 (s), 6.62 (d, $J=9.0,2.4 \mathrm{~Hz}), 6.57$ (d, $J=2.4 \mathrm{~Hz}), 6.40$ (d, $J=2.0 \mathrm{~Hz}), 6.19$ (d, $J=2.0 \mathrm{~Hz}), 5.37$ (d, $J=7.7 \mathrm{~Hz}), 5.03$ $(\mathrm{d}, J=7.6 \mathrm{~Hz})$ 로 나타나 앞선 분획물들과 상당히 상이하게 나타 났고 이 분획물은 항균 효과가 크지 않았다.

본 결과와 apigenin의 NMR을 비교하는 자료로는 Telange et al.(2017)의 연구(20)의 결과에서 제시된 apigenin의 NMR을 이 용하였다. Telange et al.(2017)의 결과를 보면, ${ }^{1} \mathrm{H}$ 의 chemical shift는 12.93 (s, 1H, 5-OH), 10.72 (s, 1H, 7-OH), 10.27 (s,

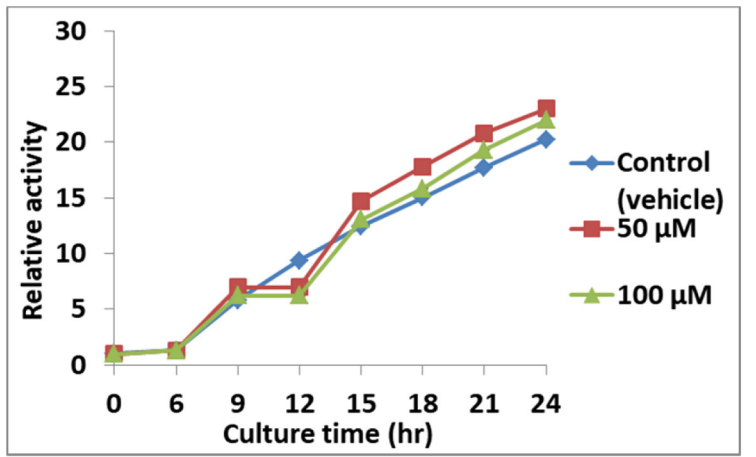

(A) Cosmosiin

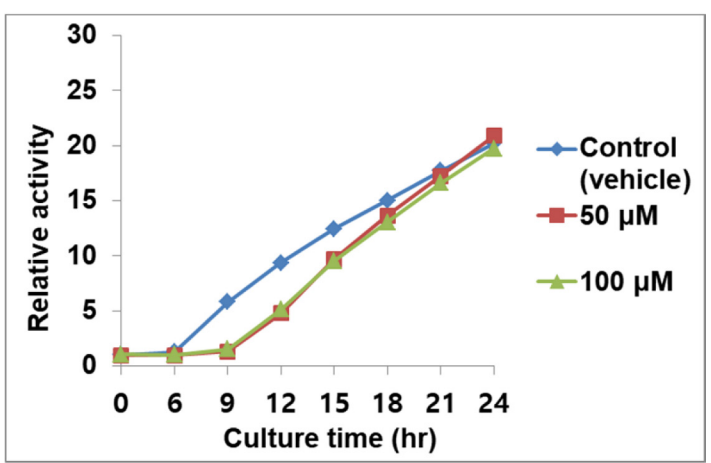

(B) Apigenin

Fig. 5 Between cosmosine and apigenin, apigenin showed antibacterial effects against $S$. aureus. 


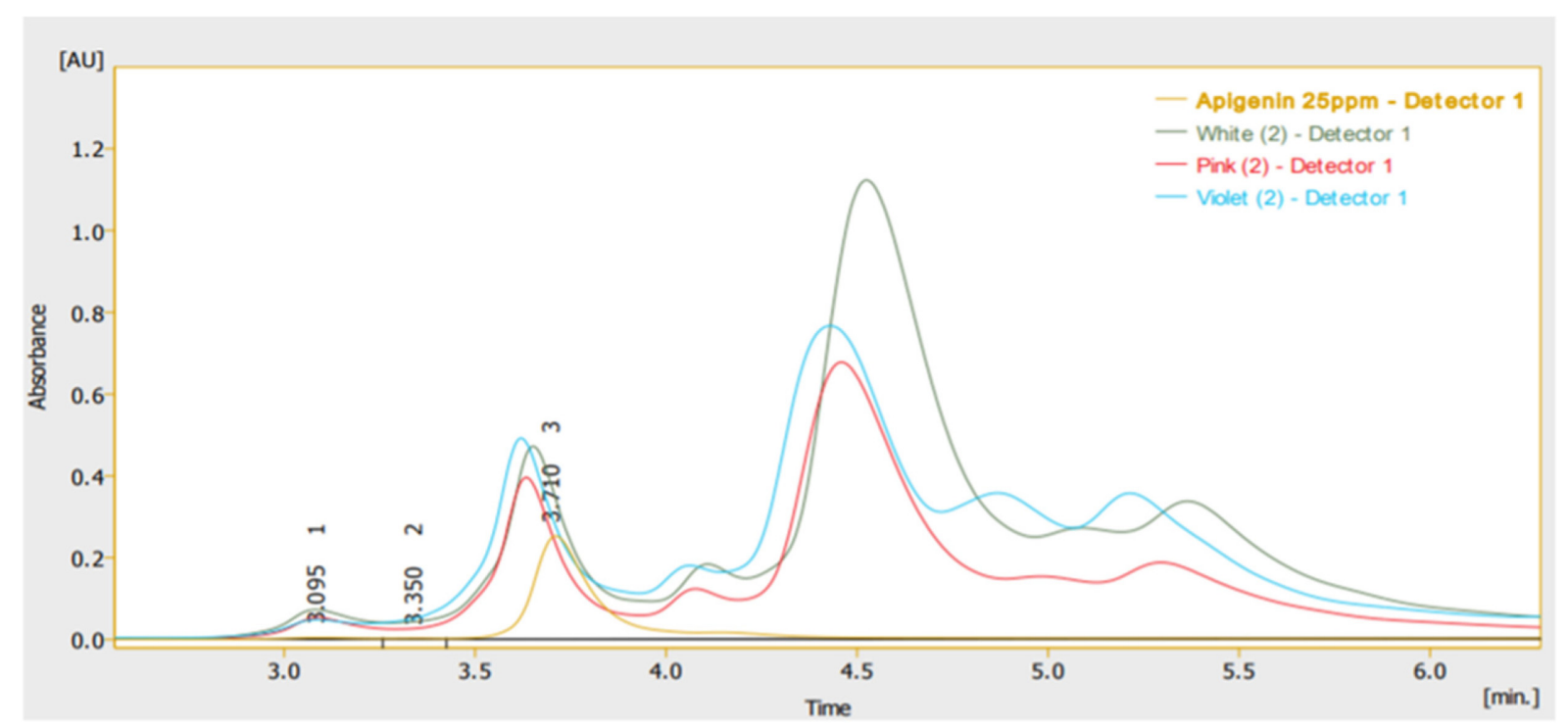

Fig. 6 HPLC spectra of EtOAc fractions of Cosmos bipinnatus Cav.flowers and apigenin at $250 \mathrm{~nm}$ : white (2)- EtOAc fraction of white flowers, pink (2)- EtOAc fraction of pink flowers, violet (2)- EtOAc fraction of violet flowers

$\left.1 \mathrm{H}, 44^{\prime}-\mathrm{OH}\right), 7.87\left(\mathrm{~d}, 2 \mathrm{H}, \mathrm{H} 3^{\prime} / \mathrm{H} 5^{\prime}\right), 6.92\left(\mathrm{~d}, 2 \mathrm{H}, \mathrm{H} 2^{\prime} / \mathrm{H} 6^{\prime}\right)$, $6.71(\mathrm{~s}, 1 \mathrm{H}, \mathrm{H} 3), 6.44(\mathrm{~d}, \mathrm{H} 8), 6.18(\mathrm{~d}, \mathrm{H} 6)$ 이다. 이를 코 스모스꽃 분획물들의 NMR의 chemical shift와 비교해 보면 $6.92\left(\mathrm{~d}, 2 \mathrm{H}\right.$, 유사 $\left.\mathrm{H}^{\prime} / \mathrm{H} 6^{\prime}\right), 6.71(\mathrm{~s}, 1 \mathrm{H}, \mathrm{H} 3), 6.44$ (d, H8), $6.18(\mathrm{~d}, \mathrm{H} 6)$ 에서 동일한 peak이 관찰되기에 본 연구의 분획물 내에도 apigenin구조 요소가 존재할 가능성을 타진할 수 있었다.

\section{HPLC 분석}

코스모스꽃 $\mathrm{EtOAc}$ 층 분획물에 존재하는 물질에 대한 분석을 위 해 HPLC 분석을 진행하였다. 항균 효과가 우수한 코스모스꽃 $\mathrm{EtOAc}$ 층 분획물과 apigenin에 대한 HPLC 분석 결과는 다음과 같다(Fig. 6). 그 결과를 살펴 보면, 흰색 코스모스꽃 $\mathrm{EtOAc}$ 층 분획물은 $\mathrm{Rt}=3.652$ (17\%), $\mathrm{Rt}=4.525$ (41.8\%)에서 주요한 peak 들이 나타났다. 분홍색 코스모스꽃 $\mathrm{EtOAc}$ 층 분획물은 $\mathrm{Rt}=3.633$ (23\%), Rt=4.458 (39.7\%)에서 peak들이 관찰되었고 자주색 코 스모스꽃 $\mathrm{EtOAc}$ 층 분획물은 $\mathrm{Rt}=3.620$ (19\%), Rt=4.430 (29.7\%) 에서 peak들이 측정되었다. 이와 함께 유추 물질인apigenin을 살 펴보면, $\mathrm{Rt}=3.710 \mathrm{~min}$ 에서 peak이 관찰되었다. 이를 통해서 코 스모스꽃 $\mathrm{EtOAc}$ 층 분획물에도 apigenin의 peak과 유사한 시간 대에 비중이 있는 peak을 확인할 수 있었기에 apigenin의 존재 가능성을 유추할 수 있었다. 그러나 3종의 코스모스꽃 EtOAc 층 분획물들의 우수한 항균 활성에 비해 apigenin의 항균 효과 가 크지 않았던 점과 HPLC결과를 통해 apigenin은 코스모스꽃 분획물의 항균 활성의 결정적인 물질은 아닌 것으로 판단된다. 그러나 apigenin 구조 요소를 포함한 활성 성분이 항균 활성을 발휘하였거나 비중이 높게 나타났던 peak의 성분이 항균 활성 물질일 것으로 추측된다.

\section{초 록}

본 연구는 코스모스꽃 추출물이 박테리아에 대해서 항균 활성 이 있는지를 알아보고 이를 통해 항균 효과를 내는 물질에 대 해 규명하고자 하였다. 흰색, 분홍색, 자주색의 코스모스꽃이 4 종의 박테리아인 S. aureus, S. epidermidis, P. aeruginosa, E. coli 에 대해 항균 효과가 있는지 접종 후 $24 \mathrm{~h}$ 동안 관찰하였다. 3 종의 꽃 추출물 중에 $\mathrm{EtOAc}$ 층 분획물에서 4개의 박테리아에 대해 가장 우수한 항균 활성이 관찰되었고 $S$. aureus에 대해서 는 $\mathrm{CHCl}_{3}$ 층 분획물도 효과를 보였다. 추가적으로 흰색 코스모 스꽃 silica gel Fr. 1과 분홍색 코스모스꽃 silica gel Fr. 2, 자 주색 코스모스꽃 silica gel Fr. 1은 $0.1 \mathrm{mg} / \mathrm{mL}$ 에서 최소저해농 도가 나타났다. 이 분획물들과 코스모스 내에 존재할 것으로 유 추되는 apigenin 간의NMR과 HPLC 비교, 분석한 결과를 통해 서 유효 성분내에는 apigenin구조 요소가 함유되어 있는 물질이 있을 것으로 판단되었다.

Keywords 고성능 액체 크로마토그래피 - 아피제닌 · 에틸아 세테이트분획 · 코스모스 · 핵자기공명

감사의 글 본 연구는 동덕여자대학교 교내 연구비 (2019) 지원에 의해서 수 행되었습니다.

\section{References}

1. Dubey S, Singh VK (2011) Population dynamics of Aphis spiracecola Patch (Homoptera: Aphididae) on medicinal plant Cosmos bipinnatus in 
eastern Uttar Pradesh, India. Adv Life Sci 1: 54-58. doi: 10.5923/ j.als.20110102.10

2. Edward FG, Teresa H (1999) Salvia splendens. Institute of Food and Agriculture Sciences, Dissertation, University of Florida

3. Alexandros SB (2007) Plants used traditionally to treat malaria in Brazil. J Ethnobiol Ethnomed 3:18, doi:10.1186/1746-4269-3-18

4. Molder M, Owens JN (1985) Cosmos. CRC handbook of flowering. CRC, Boca Raton

5. Woo JH, Shin SL, Lee CH (2010) Antioxidant effects of ethanol extracts from flower species of compositae plant. J Korean Soc Food Sci Nutr 39: 159-164, doi: 10.3746/jkfn.2010.39.2.15

6. Woo J, Shin S, Chang Y, Lee C (2010) Antioxidant effect according to extraction method in extracts of Dendranthema zawadskii var. yezoense and Cosmos bipinnatus. Kor J Hort Sci Technol 28: 462-468

7. Lee YG, Lee J, Lee NY, Kim NK, Jung DW, Wang W, Kim Y, Kim HG, Nguyen TN, Park H, Baek NI (2017) Evaluation for the flowers of compositae plants as whitening cosmetics functionality. J Appl Biol Chem 60: 511. doi: 103839/jabc.2017.002

8. Shin YH (2020) A Study on Antioxidant and Antimicrobial Activities of Cosmos bipinnatus Flower Extracts for Cosmeceutical Formulations. Dissertation, University of Hannam

9. Woo WS (2014) Natural chemical research method. Seoul University Publishing Center, Seoul, pp 63-64

10. Friend J (1979) Phenolic substances and plant disease. In: Swain T, Harborne JB, Van Sunere CF (eds) Biochemistry of Plant Phenolic, Plenum Press, New York, pp 557-588

11. Friend J (1976) Lignification in infected tissue. In: Friend J, Threlfall DR (eds) Biochemical Aspects of Plant-Parasite Relationships, Academic Press, London

12. Jang (2013) Radical Scavenging and Tyrosinase Inhibitory Effects of the
Extracts and Fractions of Asteraceae Medicinal Plants. Dissertation, University of Sunchon

13. Jang IC, Park JH, Park E, Park HR, Lee SC (2008) Antioxidative and antigenotoxic activity of extracts from cosmos (Cosmos bipinnatus) flowers. Plant foods Hum Nutr 63: 205-210, doi: 10.1007/s11130-0080086-8

14. Akihisa T, Yasukawa K, Oinuma H, Kasahara Y, Yamanouchi S, Takido M, Kumaki K, Tamura T (1996) Triterpene alcohols from the flowers of compositae and their anti-inflammatory effects. Phytochem 43: 1255 1260, doi:10.1016/S0031-9422(96)00343-3

15. Kim SY, Lee MH, Park SN (2010) Evaluations of antioxidative activity and whitening effect of extracts from different parts of Cosmos bipinnatus. J of the Korean Oil Chemists' Soc 27: 559-567

16. Olajuyigbe O, Ashafa A (2014) Chemical composition and antibacterial activity of essential oil of Cosmos bipinnatus Cav. leaves from South Africa. Iran J Pharm Res 13: 1417-1423, doi 10.22037/ijpr.2014.1581

17. Lee SE, Kim S (2009) Composition and cytotoxicity of Essential Oil Extracted from Cosmos bipinnatus Cav. Weed Turf Sci (Conference) 29: 70-72

18. Shibamoto $\mathrm{T}$ (1987) Retension indices in essential oil analysis. In: Sandra P, Bicchi C (eds.) Capillary gas chromatography in essential oils analysis, Huethig, Heidelberg, pp 259-274

19. Saito K (1979) Quantitative variation of flavonoids and related compounds in Cosmos bipinnatus. Acta Soc Bot Pol 48: 317-325, doi: 10.5586/asbp.2011.020

20. Telange DR, Patil AT, Pethe AM, Fegade H, Anand S, Dave VS (2017) Formulation and characterization of an apigenin-phospholipid phytosome (APLC) for improved solubility, in vivo bioavailability, and antioxidant potential. Eur J Pharm Sci 108: 36-49, doi.org/10.1016/j.ejps.2016.12. 009 